MINERALOGIA, 42, No 2-3: 93-112 (2011)

DOI: 10.2478/V10002-011-0009-4

www.Mineralogia.pl

MineRALOGICAL SOCIETY OF PolAND

Polskie TOWARZYSTWO MINERALOgICZNE

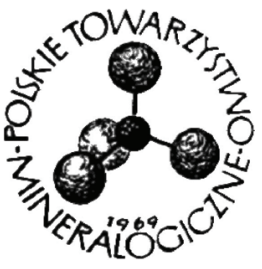

Original paper

\title{
Diagenetic signals from ancient human remains - bioarchaeological applications
}

\author{
Krzysztof SZOSTEK $^{1 *}$, Beata STEPAŃCZAK ${ }^{1}$, Anita SZCZEPANEK ${ }^{1}$, \\ Małgorzata KEPAA ${ }^{1}$, Henryk GŁĄ ${ }^{1}$, Paweł JAROSZ ${ }^{2}$, Piotr WŁODARCZAK ${ }^{2}$, \\ Krzysztof TUNIA ${ }^{2}$, Jacek PAWLYTA ${ }^{3}$, Czesława PALUSZKIEWICZ ${ }^{4}$, \\ Grzegorz TYLKO ${ }^{5}$ \\ ${ }^{1}$ Department of Anthropology, Institute of Zoology, Jagiellonian University, Kraków, Poland; \\ e-mail: szosy@wp.pl \\ ${ }^{2}$ Institute of Archaeology and Ethnology PAN, Kraków, Poland \\ ${ }^{3}$ Department of Radioisotopes, Institute of Physics, Silesian University of Technology, Gliwice, Poland \\ ${ }^{4}$ Faculty of Materials Science and Ceramics, AGH University of Science and Technology, Kraków, Poland \\ ${ }^{5}$ Department of Cytology and Histology, Institute of Zoology, Jagiellonian University, Kraków, Poland \\ * Corresponding author
}

Received: May 20, 2011

Received in revised form: November 8, 2011

Accepted:January 18, 2012

Available online: March 30, 2012

Abstract. This preliminary study examines the potential effects of diagenetic processes on the oxygen-isotope ratios of bone and tooth phosphate $\left(\delta^{18} \mathrm{O}\right)$ from skeletal material of individuals representing the Corded Ware Culture (2500-2400 BC) discovered in Malżyce (Southern Poland). Intra-individual variability of Ca/P, CI, C/P, collagen content $(\%)$ and oxygen isotopes was observed through analysis of enamel, dentin and postcranial bones. Using a variety of analytical techniques, it was found that, despite the lack of differences in soil acidity, not all the parts of a skeleton on a given site had been equally exposed to diagenetic post mortem changes. In a few cases, qualitative changes in the FTIR spectrum of analysed bones were observed. The data suggest that apart from quantitative analyses, i.e., the calculation of $\mathrm{Ca} / \mathrm{P}, \mathrm{CI}, \mathrm{C} / \mathrm{P}$ and collagen content, qualitative analyses such as examination of the absorbance line are recommended. The degree to which a sample is, contaminated on the basis of any additional, non-biogenic peaks, deemed to be contaminated should also be specified.

Key-words: diagenesis, Neolithic, oxygen isotopes, FTIR, EDS, bioarchaeology 


\section{Introduction}

Chemical analyses of prehistoric and historical bone material provide us with a complex body of knowledge in bioarchaeological studies. They can be used for reconstructing diet, migration, climate changes and the weaning process. An important aspect is that the analysis of enamel, dentin and bones allows researchers to gather data on the life strategies of an individual by retrospectively tracing his various ontogenetic phases.

A significant element of isotope tests is the way in which short time periods (life periods) can be examined through analyses of different fragments of the skeleton (enamel, dentin, bone). They retrospectively reconstruct the life histories of individuals against the studied group in terms of diet, weaning effect and migration. Due to their varying rates of remodelling, compact bone provides information dating back to ca 10 years before the individual's death. By studying the different parts of deciduous and permanent teeth, e.g., enamel and dentin, we may retrace the life strategies of a given individual in relation to different periods of their childhood and adolescence. This is made possible by taking account of differences between enamel and dentin, and of differences in bone remodelling rates depending on the age of the individual, in the light of the known mineralization periods of individual types of deciduous and permanent teeth. Diagenetic alterations of bone are known to have a significant influence on the data derived from stable isotope analyses of archaeological material. The quantification of potential diagenetic changes observed in historical, human bone material is currently the major trend in bioarchaeological research. As we know, different elements of the skeleton vary in their sensitivity to diagenetic agents. Thus, the large interpretative potential of isotope analyses is severely limited by unpredictable taphonomic processes.

Consequently, research employs a specialized and complex set of techniques and methods that can verify post mortem changes in the chemical structure of the material and allow the precise interpretation of the results of isotopic studies.

In the context of stable-isotope analyses, diagenesis should be considered in terms of both the preservation of organic components of bones and teeth (collagen) and of the mineral part (hydroxyapatite). As a result, verification of the extent to which samples are preserved should be multidimensional. There are differences in susceptibility to diagenesis between the organic and mineral components of bone. Generally, the inorganic fraction of bone is more susceptible to post mortem diagenetic changes than is collagen (Krueger 1991; Lee-Thorp, van der Merwe 1991; Pearsal 2008).

Therefore, emphasis is put on detailed descriptions of any post mortem changes relating to the bone mineral. At present, verification of diagenetic changes in the bone apatite involves the application of a set special, complementary techniques and methodologies. These include detailed analyses of the soils from the grave and its surroundings to determine their physical and chemical properties, and to determine the bone-mineral $\mathrm{Ca} / \mathrm{P}$ ratio, the crystallinity index of its phosphates and carbonates $(\mathrm{CI})$ and its carbonate/phosphate ratio $(\mathrm{C} / \mathrm{P})$. Crucially, it is the skeleton enamel that is the part most resistant to diagenetic changes (Ambrose, Norr 1993; Ballasse 2003; Kohn et al. 1999; LeeThorp, Sponheimer 2006; Lee-Thorp, van der Merwe 1991). Studies by Sponheimer and Lee-Thorp (2006) reveal that analyses of fossilized enamel of various animal species dating back millions of years reflect biogenic concentrations of trace elements. Because enamel 
also undergoes post mortem changes in specific circumstances, verification of preservation should be carried out on as many parts of the skeleton (enamel, dentin, compact bone) as possible. The fact that, for example, enamel does not undergo diagenetic changes does not mean that other parts of the skeleton reveal the ante mortem biogenic chemical composition of an individual. As all parts of the skeleton varied in terms of mineralization age and remained unchanged with respect of remodelling rate (intra vitam biogenic signal), it is possible to reconstruct the life strategies of the individual. Interpretation of the chemical signals from enamel and dentin in relation to their mineralization age and low remodelling enables a retrospective reconstruction, accurate to several months, of the life history of an individual to be performed. In the case of bones, remodelling and turnover run at different rates depending on an individual's age. Longinelli (1984) demonstrated experimentally that this rate decreases with age.

The actual moment when diagenetic processes begin within the cortex of bone is difficult to determine. Different authors give estimates ranging from several tens of days (Bell et al. 1996) to several years after death (Yoshino et al. 1991). Likewise, the factor responsible for the initiation of diagenetic processes has not yet been definitively indentified. The most likely cause of diagenesis seems to be the early action of microorganisms such as bacteria, cyanobacteria (in aquatic environments) or fungi, which penetrate into the bone (Hedges 2002; Jans et al. 2004). The main effect of the enzymes produced by those microorganisms is a gradual loss of organic bone components, particularly collagen (Collins et al. 2002). Diagenesis affects the bones of children and adolescents most rapidly, since these bones are not completely mineralised (Buckberry 2000). Bone porosity increases by as much as $50 \%$ due to the mechanical and enzymatic activity of microfauna (Jans et al. 2004). Thus, the bone becomes even more susceptible to the influence of external diagenetic factors. Surface water penetrating empty spaces leads not only to the washing out organic components but, most importantly, inorganic components of the bone tissue and their replacement by geogenic elements such as fluorine, calcite, strontium and uranium (Lee-Thorp 2002; Wright, Schwarcz 1996). Advancing recrystallization and a change in the size of bone apatite crystals leads to the fossilization of the bone material. The above processes take place far more slowly in tooth enamel because of its low content of organic substances and large hydroxyapatite crystals.

The rate of post mortem change observed in the skeleton is heavily dependent on the geochemical environment of burial. In neutral $\mathrm{pH}$ soils, usually characterised by a concentration of calcium cations and phosphate anions similar to that in bone apatite, the degradation of the bone mineral occurs far more slowly (Hedges 2002). Low and high soil $\mathrm{pH}$ accelerates the process, as do increased hydrological activity and high solar radiation intensity. Reduced activity by microorganisms in bones deposited in waterlogged oxygendeficient areas, and in very dry areas, has been reported (Hedges 2002; Stephan 1997).

Oxygen is incorporated into bone apatite during the process of bone and tooth mineralisation. Its isotope content depends on the isotope ratio of the body water (LeeThorp 2002; Luz et al. 1984). Of the three potential components containing oxygen atoms in bone apatite $\left(\mathrm{PO}_{4}{ }^{3-}\right.$ phosphates, $\mathrm{CO}_{3}{ }^{2-}$ carbonates and $\mathrm{OH}^{-}$groups $)$, phosphates contribute the highest fraction of oxygen atoms (85-95\%; Brady et al. 2008). Bone carbonates, constituting $\sim 6 \%$ of apatite, form in isotopic equilibrium with the body-liquid bicarbonates of an organism over the course of its life. 
In enamel, a more chemically stable tissue, $\mathrm{CO}_{3}{ }^{2-}$ substitution amounts to $<3 \%$ (LeeThorp 2002). Following death, carbonate ions from sedimentary calcium carbonate frequently accumulate in the free spaces in bones and on the surface of their crystalline structure, distorting the results of oxygen isotope measurements. Additionally, the C-O bonds are easily broken and oxygen is exchanged for water, which penetrates post mortem into bone spaces. P-O bonds are stronger than C-O bonds, making the substitution of oxygen ten times less common and, thus, providing a better measure of the intra vitam proportion of oxygen isotopes (Zazzo et al. 2004). As is currently believed, only enzymes produced by microorganisms could significantly accelerate the degradation of phosphates. Such enzymes have the ability to catalyze the breaking of P-O bonds (Kohn et al. 1999; Zazzo et al. 2004). Although phosphates are the most enduring component of bone mineral, the progress of even their decomposition requires evaluation. Today, a highly specialised set of methods and research tools is used to verifying whether bone remains from archaeological sites are suitable for use in isotope studies.

The aim of the research reported here was to describe the diagenetic processes in the enamel, dentine and various post-cranial skeletal sections from a single individual. Analyses were carried out on various interpretative levels: intra-individual and interindividual variability in the light of the individual's sex and age, and the $\mathrm{pH}$ of the soil from the investigated graves.

\section{Site and sample description}

The skeletal material used for the preliminary assays came from three individuals (Grave10: male, 35-40 years old; Grave 11: 12 months old, Grave 12: 10-11 years old) from Corded Ware Culture (2500-2400 BC) discovered in Małżyce (Southern Poland) (Fig. 1).

The anthropological analysis was performed by Szczepanek (2009) according to standard methods (White, Folkens 2005). The excavations were conducted by Jarosz, Włodarczak and Tunia. The research was financed from resources granted by the Minister of Culture and National Heritage (the Cultural Heritage Programme, Priority 4: Archaeological Monument Preservation, agreement no. 11065/08/FPK/KOBiDZ).

The site in Malżyce is situated at a local culmination ( $307 \mathrm{~m}$ above sea level) of the elevation in the eastern part of the Proszowice Plateau (Kondracki 2000). A darker circular spot with limestones in its centre was clearly visible in the place of the tomb even before the exploration. During excavations below humus, a layer of dark yellow loess, damaged by frequent animal burrowing, was noted. The layer, unlike those at many other "loess" sites, was a very dark brown colour, which is typical of heavily degraded soils (Jarosz et al. 2009). Below it, a layer of light yellow loess with numerous small calcareous precipitations began at the depth of $80 \mathrm{~cm}$. The stratigraphy is shown in photos of the profiles of the niche graves (Fig. 2). The loess substratum caused many problems in the demarcation of archaeological features, the entrance pits to the Corded Ware Culture (CWC) niche graves in particular. 


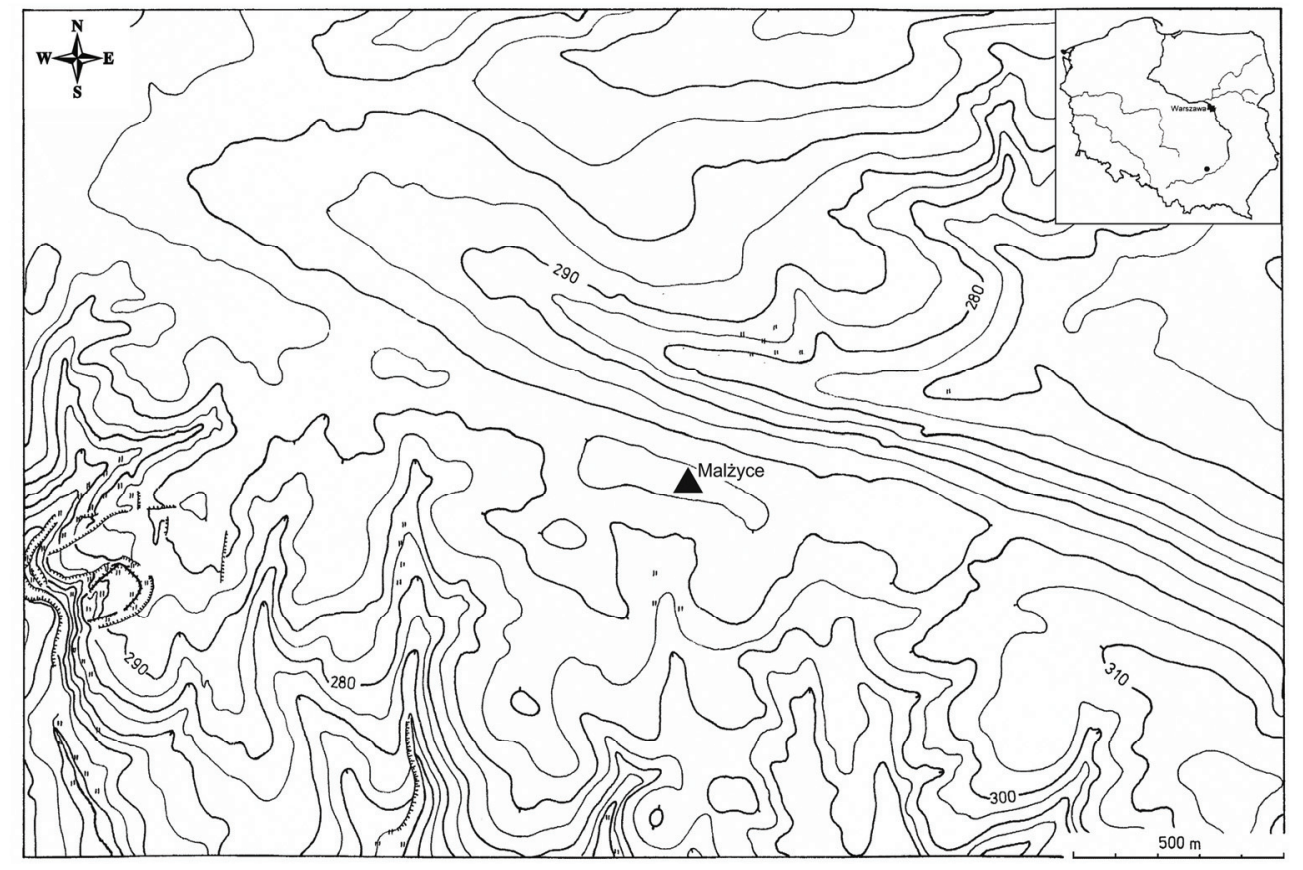

Fig. 1. Location of Barrow No. 2 at Site 30 in Malżyce, Commune of Czarnocin, Świętokrzyskie province.

Over a considerable part of the excavation unit, a brown and yellow layer (marked as Layer 1) typical of prehistoric fills of large depressions and original soil levels was documented below the arable soil. Only its western and southern edges were not covered by the unit. The layer was probably a component of the lower section of the embankment or a surviving part of the original soil level.

From the north, Layer 1 was bordered by a strip of slightly darker soil, rather irregular in its outline. Its shape and location suggested that it was the vestige of a structure enclosing the embankment of the tomb. Within the western and eastern parts of the strip, there were isolated limestones.

In the middle part of the excavation unit, a Funnel Beaker Culture (FBC) central grave (Feature 1) was uncovered at the eastern edge of Layer 1. Two pit graves with poorly-preserved skeletal burials were situated south of this feature and four CWC features, including three niche graves (features 10,11,12) lay east of the tomb suggesting that a small cemetery had been established near the embankment of the older tomb (Fig. 3). 


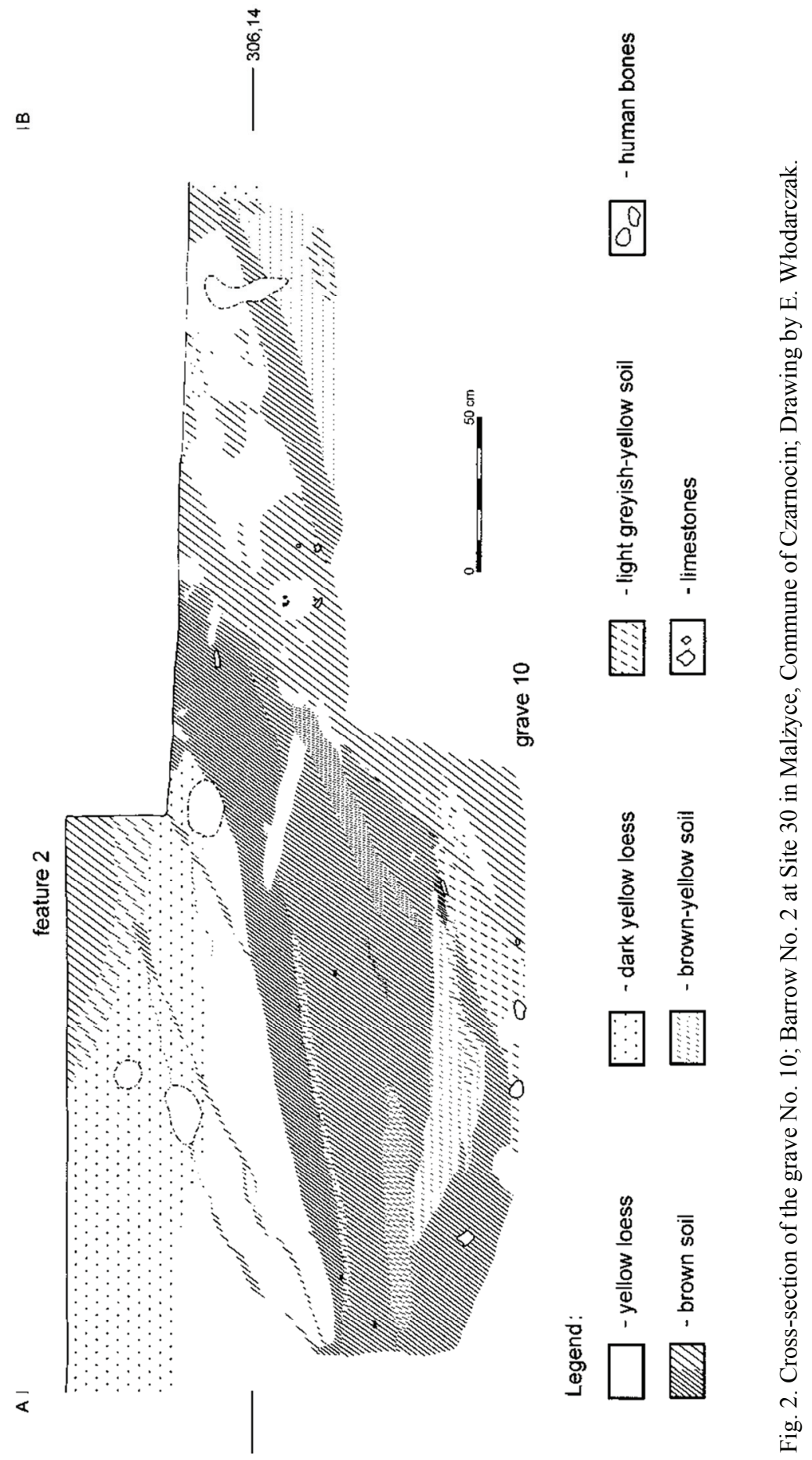




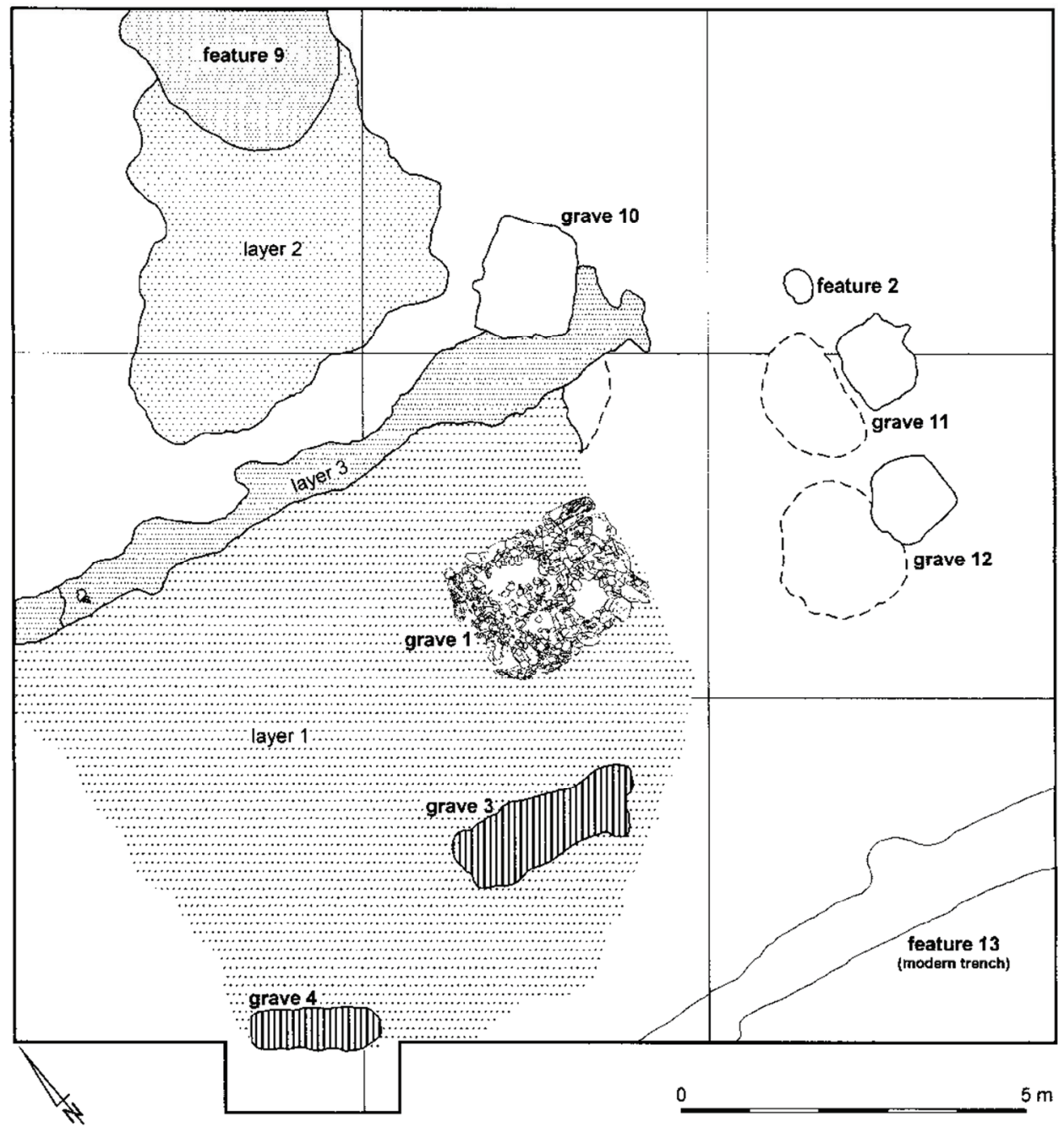

Fig. 3. Plan of an excavation unit; Barrow No. 2 at Site 30 in Malżyce, Commune of Czarnocin.

The niche graves were typical of those known from sites of the Kraków-Sandomierz CWC group (Włodarczak 2006). Inside each, a short gallery sloped down from the entrance pit toward the grave niche. Skeletons were laid at the bottom of the niches $120 \mathrm{~cm}$ (Grave 11 and 12) and $180 \mathrm{~cm}$ (Grave 10) below the current ground level. The niches had similar fills consisting mainly of dark brown soil that filled them to their roofs, as well as a few traces (blocks of loess) of collapsed roof. For that reason, their outlines remained undamaged and easily discernible. The analysis of their fills and the arrangement of bones indicate that the niches filled only gradually with sediment deposited by water that came from the direction of the entrance. By contrast, the entrance pits contained diverse layers, including much yellow loess. They were probably filled quickly with material dug up during the construction of the graves. 
Radiocarbon measurements of human bones from the analysed graves in Malżyce were made in the Poznan Radiocarbon Laboratory. Samples from Grave 1 were dated at 3630-3370 BC, a temporal bracket that may be linked explicitly to the classical phase of the FBC. The CWC graves were dated at approx. 2500-2400 BC, corresponding to radiocarbon datings of other graves in the Krakow-Sandomierz group. On the basis of both absolute and relative chronologies, it may therefore be assumed that the tomb in Malżyce was used in two phases separated by nearly a thousand years - the first phase related to the FBC and the second to the Krakow-Sandomierz CWC group. Skeletons of the CWC were selected for our investigations because of the comparable chronology, localization and varied ages of death.

\section{Material}

Enamel, dentine and several elements of post-cranial skeleton were collected from each individual for analyses. Additionally, 8 soil samples derived from the host site were also collected. Analysis of intra-individual and inter-individual variability was based on the following skeletal elements: Grave 10. (enamel M2, enamel M3, dentine M2, dentine M3, vertebra, femur), Grave 11. (enamel $\mathrm{m} 2$, dentine $\mathrm{m} 2$, femur), Grave 12. (enamel M2, dentine M2, femur, rib).

The oxygen isotope analysis method used involved collecting half of the enamel from a tooth across the crown area and of primary dentin along the entire root, due to the sample weight required (ca $40 \mathrm{mg}$ ). Tooth formation occurs sequentially and, following complete mineralisation, a given layer does not undergo isotopic reconstruction in the case of enamel and only slight reconstruction in the case of primary dentin. Thus, it is assumed that the oxygen isotope ratio in enamel or dentin is representative of the whole mineralisation period of a given structure, not only of its final phase. The time intervals of tooth tissues selected for analysis are presented in Table 1.

TABLE 1

The timing of formation of the sampled teeth.

\begin{tabular}{lllll}
\hline & \multicolumn{2}{l}{ Enamel mineralization } & \multicolumn{2}{l}{ Root dentine mineralization* } \\
\cline { 2 - 5 } & Initiation & Complete & Initiation & Complete \\
\hline m2 tooth & $6 \mathrm{mth}^{* *}$ & $10 / 12 \mathrm{mth}$ & $10 / 12 \mathrm{mth}$ & $3 \mathrm{yrs}$ \\
M2 tooth & $2.5 / 3 \mathrm{yrs}$ & $6 / 8 \mathrm{yrs}$ & $6 / 8 \mathrm{yrs}$ & $13.5 / 16.5 \mathrm{yrs}$ \\
M3 tooth & $8 / 11 \mathrm{yrs}$ & $12 / 15 \mathrm{yrs}$ & $12 / 15 \mathrm{yrs}$ & $17.5 / 21 \mathrm{yrs}$ \\
\hline
\end{tabular}

* primary dentine

** prenatal period 


\section{Analytical methods}

It is well known that both the $\mathrm{pH}$ value of soil and the concentrations of elements in it have a potent effect on the ultimate values of chemical analyses in osteological material. Therefore, prior to the analysis of bone material, the $\mathrm{pH}$ of the soil was tested as one of the main factors affecting chemical change in the skeleton after death.

\subsection{Energy dispersive X-ray spectroscopy}

The calcium/phosphorus ratio was determined using energy dispersive X-ray spectroscopy. $\mathrm{Ca} / \mathrm{P}$ is an indicator of the extent of the mineralisation of the osteological material. In a diagenetically unchanged bone or tooth, $\mathrm{Ca} / \mathrm{P}$ should fall within the range of $1.8-2.7$ with contents of $\mathrm{Ca} \approx 37 \mathrm{wt} \%$ and $\mathrm{P} \approx 17 \mathrm{wt} \%$ (Kohn et al. 1999). Degradation and diagenetic substitutions for calcium and, less commonly, for phosphorus will affect the final value of $\mathrm{Ca} / \mathrm{P}$. It is deviation in phosphorus concentration that may reflect the contamination of phosphate apatites and, thus, signal potential distortion of the oxygenisotope data (Kohn et al. 1999; Fabig, Herrmann 2002). Cross-sections of teeth were thoroughly attached to the microscope specimen holder with conductive adhesive cement and carbon coated in a vacuum evaporator (JEOL JEE-4C, Tokyo, Japan). The surfaces of tooth dentin and enamel were polished before X-ray microanalysis which involved the use of a JEOL JSM 5410 scanning electron microscope equipped with Noran energy dispersive spectrometer (Noran Instruments Inc., WI, USA) consisting of a $30 \mathrm{~mm}^{2} \mathrm{Si}(\mathrm{Li})$ crystal covered with a Norvar ultrathin window. Elemental analyses were performed in the raster mode over the surface of specimens scanned at 750x magnification. Analytical conditions chosen for both regions of the specimens were as follows: accelerating voltage $30 \mathrm{keV}$, take-off angle $25^{\circ}, 40 \mathrm{~mm}$ of detector working distance, $0.0187 \mathrm{sr}$ solid angle, tilt angle $0^{\circ}$ and probe current $120 \mathrm{pA}$. The final count rate of the detection system did not exceed $2500 \mathrm{cts} / \mathrm{s}$ and measurements were performed over 500s. Quantitative analyses were performed using an apatite standard (SPI ${ }^{\circledR}$ Supplies, West Chester, USA) measured under the same analytical conditions. Net intensities of characteristic X-rays of elements obtained from teeth were compared to those from the apatite standard. Minimum detection limits for elements of interest were calculated on the basis of apatite spectra using the equation proposed by Goldstein and Yakowitz (1975).

\subsection{Fourier Transform Infrared Spectroscopy}

In the stable-isotope analysis of apatite phosphates and of carbonates, the recognition of diagenetic processes involves determining the extent to which the bones are crystallised. Despite the fact that phosphate groups are less susceptible than are carbon groups to post mortem changes, it does not mean that such changes cannot occur. Post mortem substitution of phosphorus with ions primarily involves $\mathrm{Si}, \mathrm{Al}$ and B (Kohn et al. 1999). Currently, the most frequently used reference method for studying changes in bone apatite crystallisation and their diagenetic changes, i.e., of the phosphate group $\left(\mathrm{PO}_{4}\right)$, is Fourier Transform Infrared Spectrometry (FTIR; White et al. 1998). Analyses of the spectrum of the powdered bone allows the crystallinity index $(\mathrm{CI})$, reflecting changes in bone structure, to be specified 
For contemporary bones, CI ranges from 2.50-3.3 (Thompson et al. 2009). For osteological material, CI values should not exceed 3.5 (preferably $<3.3$ ). This gives the basis for establishing the extent of any diagenetic changes due to destruction of phosphate radicals in the apatite. For this reason, FTIR was used in this study.

From the ratio of the absorbance peak height at the wavelengths of 1415 and $1035 \mathrm{~cm}^{-1}$ characteristic respectively of carbonate and phosphate groups $\left(\mathrm{C} / \mathrm{P}=\mathrm{A}_{1415} / \mathrm{A}_{1035}\right)$, the degree of contamination of bone apatite by exogenous carbonates can be estimated. For contemporary bones, the $\mathrm{C} / \mathrm{P}$ is $\sim 0.34$; when $>0.5$, the incorporation of extrasomatic $\mathrm{CO}_{3}{ }^{2-}$ ions in the crystalline lattice of apatite is indicated. Moreover, when calcite $\left(\mathrm{CaCO}_{3}\right)$ has been incorporated into the bone mineral, a peak is present at the wavelength of $710 \mathrm{~cm}^{-1}$ (Nielsen-Marsh, Hedges 2000; Wright, Schwarcz 1996).

Calculations of the relations between integral intensities, absorption bands generated by organic matter and bands related to the inorganic component of the bone specify the crystallinity of the material. In addition, differential analysis of the spectra enables the history of the process of bone-tissue mineralisation to be determined.

Spectra were obtained following the method of Weiner and Bar-Yosef (1990). Bone, enamel and dentin samples were milled in a Retsch MM200 agate mixer mill. Two milligrams of the powder were ground together with ca $300 \mathrm{mg}$ potassium bromide $(\mathrm{KBr})$ in an agate mortar and pestle. Pellets were created in a vacuum press under 9 tons of pressure for 5 minutes. Potassium bromide originating outside the sample served as a reference. The FTIR spectra were analyzed in the FTIR Laboratory of the AGH University of Science and Technology in Cracow using of a vacuum spectrometer equipped with a DTGS detector (Bio-Rad) with a resolution of $4 \mathrm{~cm}^{-1}$ in the range of $400-4000 \mathrm{~cm}^{-1}$.

The crystallinity index (CI) of the bone was calculated from the extent of phosphate peak splitting at 565-605 $\mathrm{cm}^{-1}$ according to the formula: $\mathrm{CI}=\left(\mathrm{A}_{565}+\mathrm{A}_{605}\right) / \mathrm{A}_{595}$ (Wright, Schwarcz 1996).

From the ratio of the absorbance peak height at the 1415 and $1035 \mathrm{~cm}^{-1}$ wavelengths, characteristic of carbonate and phosphate groups, respectively, the carbonate/phosphate index $\mathrm{C} / \mathrm{P}\left(\mathrm{A}_{1415} / \mathrm{A}_{1035}\right)$ was calculated. On the basis of this, the extent of contamination of bone apatite by extrasomatic carbonates was estimated.

\subsection{Isolating bone phosphates}

Phosphates were isolated from bone hydroxyapatite according to the procedure suggested by O'Neil et al. (1994). A bone or tooth sample milled in a Retsch MM200 agate mixer mill was suspended in a strongly oxidizing sodium hypochlorite $(\mathrm{NaOCl})$ solution and subsequently in sodium hydroxide $(\mathrm{NaOH})$ solution to remove organic substances, including humic acids. Next, the addition of hydrofluoric acid (HF) to the sample released phosphate groups from the apatites, which in reaction with buffered silver nitrate $\left(\mathrm{AgNO}_{3}\right)$, precipitated as yellow-green crystals of silver phosphate $\left(\mathrm{Ag}_{3} \mathrm{PO}_{4}\right)$.

Additionally, a silver phosphate purity index was calculated as the ratio of the mass of the obtained silver phosphate to the output quantity of the bone or tooth sample (White et al. 2004). All analyses were carried out using ultra-pure water obtained from a GEN-PURE filtering set. 


\subsection{Stable isotope analysis}

Over the last decade, a number of methods have been designed for identifying the isotope composition of oxygen in phosphates extracted from human and animal bones. Three most frequently used methods require the transfer of bone phosphates to stable hydrophobic silver phosphate (Vennemann et al. 2002). These differ in the way in which the isotope composition of the oxygen is determined. In the first method, silver phosphate is decomposed at a high temperature in the presence of powdered graphite to generate $\mathrm{CO}_{2}$. The isotope analysis of purified $\mathrm{CO}_{2}$ is performed by means of mass spectrometry (O'Neil et al. 1994). A disadvantage of this method is the fractionation of isotopes due to the deficiency of oxygen during the reaction with graphite: non-measurable quantities of carbon monoxide are generated (Lécuyer et al. 2007; LaPorte et al. 2009) the isotopic composition of which is not examined in this method. A second method involves laserassisted fluoridation of silver phosphate. The released oxygen is fed onto a heated graphite rod, leading to the generation of $\mathrm{CO}_{2}$. Although isotope fractionation does not occur (Lécuyer et al. 1996), a drawback is the considerable complexity of the measuring instruments.

The present study, the third and most commonly-used method was applied, namely, $\mathrm{Ag}_{3} \mathrm{PO}_{4}$ pyrolysis at a high temperature performed in an elemental analyser. The oxygen obtained as a result of the decomposition of silver nitrate creates carbon monoxide in reaction with glazed carbon. The carbon monoxide was then fed into the mass spectrometer through a chromatographic chamber. The isotopic composition of the sample oxygen was measured using an IsoPrime mass spectrometer coupled with a EuroVector elemental analyser.

In the study, the oxygen isotopic composition was determined in the $\mathrm{Ag}_{3} \mathrm{PO}_{4}$, with the only treatment being the overnight drying of all samples prior to measurements at $45^{\circ} \mathrm{C}$. All samples were measured in three sub-samples (Dupras, Schwarcz 2001; White et al. 2004; Evans et al. 2006). Results were averaged. Uncertainty of the measurements estimated on the basis of repeated measurements of the FlCell Ac ISONET standard was about 0.7\%.

A catalyst $(\mathrm{NiC})$ was added to each sample in a 1:1 mass ratio. The ${ }^{18} \mathrm{O}$ value for the reference standard sample NIST $120 \mathrm{c}$ was in line with literature references. The analyses were carried out in the Department of Radioisotopes, Institute of Physics, Silesian University of Technology - GADAM Centre.

\subsection{Analysis of the organic fraction of the osteological material}

Collagen was isolated by means of a weak hydrochloric acid $(\mathrm{HCl})$ and sodium hydroxide $(\mathrm{NaOH})$ to demineralise the sample and to eliminate inorganic contaminants. The final ultrafiltration (centrifuging in Amicon Ultracel test tubes -4 Millipore) made it possible to precisely separate the collagen fraction from the remaining organic substances (e.g., albumen or globulin). The last step involved freeze-drying of the samples. (Bocherens 1997; Ritsema et al. 2010).

There are, however, many factors that act to destroy collagen. Its preservation depends largely on the activity of microorganisms as was confirmed experimentally by Child (1995) and Grupe et al. $(1989,1993)$. It is, therefore, necessary to check the 
preservation of the bone organic components before stable isotope analysis. After thoroughly cleaning bones or teeth of any remains of organic substances adsorbed during deposition, the quality of preserved collagen was tested by checking the percentage of collagen isolated from the bone in proportion to its dry mass. It was proved that low percentages of collagen in bone strongly correlated with anomalous proportions of carbon and nitrogen isotopes. Collagen normally constitutes $>2 \mathrm{wt} \%$ of the mass of a wellpreserved bone (Jørkov et al. 2007). In a bioarchaeological analysis, the proportion of collagen should not be $<1 \mathrm{wt} \%$ (Ambrose 1993; Schoeninger, Moor 1992).

\section{Results and discussion}

Potential diagenetic influence on the prehistoric material was evaluated by investigating selected diagenetic parameters. Soil $\mathrm{pH}$ was analyzed to estimate the impact of the grave filling on bones. The reaction was close to neutral $(\mathrm{pH}=6.3-6.8)$, which rendered the material suitable for analysis. The collagen content in the bone samples greatly exceeds $2 \mathrm{wt} \%$ (Table 2). The percentage of collagen isolated from the bone in proportion to its dry mass (\% collagen) does not reveal diagenetic changes. Analytical results for the analysed individuals are shown in Table 2.

The completeness of the laboratory precipitation of $\mathrm{Ag}_{3} \mathrm{PO}_{4}$ was tested by examining the relation between $\mathrm{Ag}_{3} \mathrm{PO}_{4}$ yield and $\delta^{18} \mathrm{O}$ values. If there had been preferential recovery of one isotope over the other $\left({ }^{16} \mathrm{O}\right.$ or $\left.{ }^{18} \mathrm{O}\right)$, a correlation would be expected. No such was found for the analyzed material (Pearson's; $y=0.09+0.07 x ; r^{2}=4.9 \% ; p>0.05$ ).

For the tested samples, the measured $\mathrm{Ca} / \mathrm{P}$ values range from $2.06-2.35$, with $\mathrm{Ca}$ contents of 35.9-39.65wt \% and $\mathrm{P}$ contents of $15.30-18.43 \mathrm{wt} \%$. These values do not exceed the limits for well-preserved bone. In the SEM-EDS spectrum of some samples, trace quantities of iron, chlorine and aluminium are evident, which may suggest that biological components were substituted by elements originating from the grave environment. It also shows incipient diagenesis, so slight that it is not revealed by changes in $\mathrm{Ca} / \mathrm{P}$.

Outlier rejection analysis shows that all results fall within the normal range (Fig. 4). This demonstrates that they have not been diagenetically altered. Consequently, it is proposed that the condition of the preserved material was good. Based on the values of taphonomic parameters such as soil $\mathrm{pH}, \mathrm{Ca} / \mathrm{P}$ and $\%$ collagen, it can be inferred that diagenetic factors had little impact on the studied material.

Figure 5 shows CI results and limits for the analysed material. Note that in the case of the infant individual (Grave 11), the limit for enamel was exceeded (CI enamel $=3.43$ ). This could suggest a significant degree of diagenetic recrystallisation in this sample. 
Isotopic data for bone and enamel by time period, age and sex.

\begin{tabular}{|c|c|c|c|c|c|c|c|c|c|c|}
\hline Material & Sample & Period & Age & Sex & $\begin{array}{l}\delta^{18} \mathrm{O} \% 0 \\
\text { VSMOW* }\end{array}$ & $\mathrm{Ca} / \mathrm{P}$ & CI & $\mathrm{C} / \mathrm{P}$ & $\begin{array}{l}\text { Yield } \\
\mathrm{Ag}_{3} \mathrm{PO}_{4}{ }^{* *}\end{array}$ & $\begin{array}{l}\% \\
\text { collagen }\end{array}$ \\
\hline Grave no. 10 & & $\begin{array}{l}2500- \\
2400 \mathrm{BC}\end{array}$ & $\begin{array}{l}35-40 \\
\text { years }\end{array}$ & male & & & & & & \\
\hline enamel M2 UR & 1 & & & & 21.59 & 2.24 & 2.98 & 0.19 & 1.77 & \\
\hline enamel M3 UR & 2 & & & & 22.27 & 2.15 & 3.15 & 0.18 & 1.78 & \\
\hline dentine M2 UR & 3 & & & & 21.39 & 2.24 & 2.88 & 0.38 & 1.48 & 10.4 \\
\hline dentine M3 UR & 4 & & & & 18.87 & 2.32 & 3.12 & 0.30 & 1.79 & 6.2 \\
\hline vertebra & 5 & & & & 18.84 & 2.21 & 2.93 & 0.41 & 1.10 & 12.7 \\
\hline femur & 6 & & & & 19.78 & 2.24 & 2.79 & 0.43 & 1.06 & 8.2 \\
\hline Grave no.11 & & $\begin{array}{l}2500- \\
2400 \mathrm{BC}\end{array}$ & 1 year & $?$ & & & & & & \\
\hline namel m2 LL & 7 & & & & 21.82 & 2.07 & 3.43 & 0.18 & 1.79 & \\
\hline dentine $\mathrm{m} 2 \mathrm{LL}$ & 8 & & & & 19.42 & 2.07 & 3.09 & 0.24 & 1.67 & \\
\hline femur & 9 & & & & 20.02 & 2.28 & 3.1 & 0.76 & 0.75 & 7.1 \\
\hline Grave no. 12 & & $\begin{array}{l}2500- \\
2400 \mathrm{BC}\end{array}$ & $\begin{array}{l}10-11 \\
\text { years }\end{array}$ & $?$ & & & & & & \\
\hline enamel M2 LR & 10 & & & & 21.6 & 2.11 & 3.04 & 0.46 & 2.0 & \\
\hline femur & 11 & & & & 20.97 & 2.35 & 2.9 & 0.45 & 1.18 & 9.9 \\
\hline rib & 12 & & & & 18.81 & 2.18 & 2.28 & 0.57 & 1.85 & 9.6 \\
\hline dentine M2 LR & 13 & & & & 21.51 & 2.06 & 2.7 & 0.21 & 1.18 & 9.5 \\
\hline
\end{tabular}

* VSMOW - Vienna Standard Mean Ocean Water

** $\mathrm{Ag}_{3} \mathrm{PO}_{4}$ yield (in $\mathrm{mg}$ produced $/ \mathrm{mg}$ starting material)

Samples in bold are suspected to have been altered and are excluded from interpretation $\mathrm{Ca} / \mathrm{P}$ - energy-dispersive X-ray spectroscopy

$\mathrm{CI}$ - crystallinity index, Fourier Transform Infrared Spectrometry

$\mathrm{C} / \mathrm{P}$ - carbonate/phosphate ratio, Fourier Transform Infrared Spectrometry

$\mathrm{Ag}_{3} \mathrm{PO}_{4}$ yield (in mg produced/ mg starting material)

Period - Radiocarbon measurements, Corded Ware Culture (CWC)

UR, LL, LR - upper right, lower left, lower right 


\section{$\mathrm{Ca} / \mathrm{P}$ ratio}

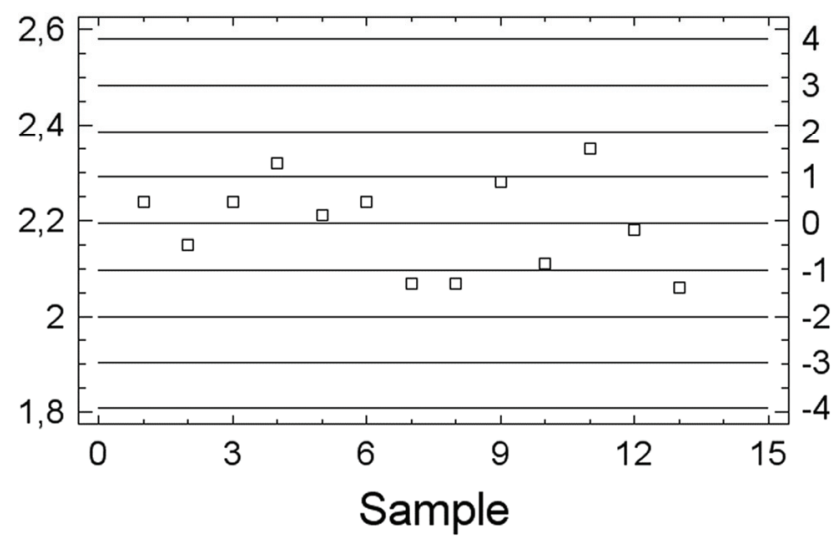

Fig. 4. Outlier plot with sigma limits for calcium-phosphorus ratio.

$\mathrm{Cl}$

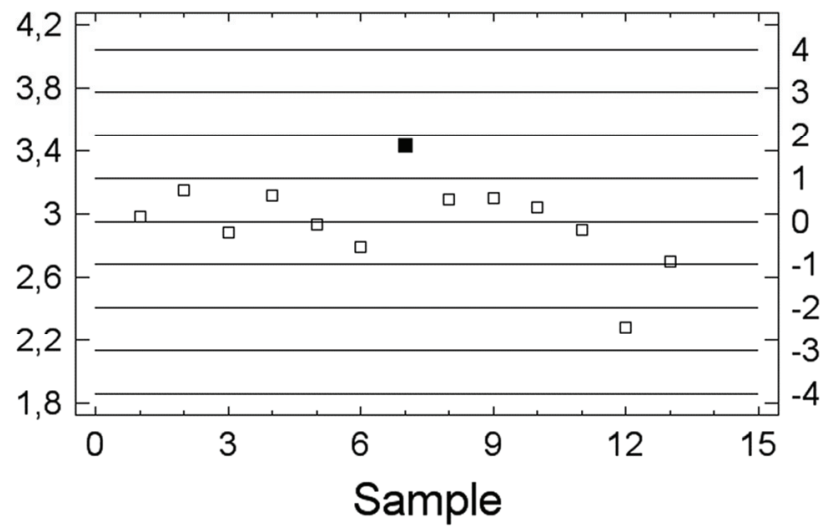

Fig. 5. Outlier plot with sigma limits for crystallinity index. Filled squares - signal of diagenetic alteration $(\mathrm{CI}>3.3)$.

For the results of stable oxygen isotope analyses to be considered reliable, there must be no linear correspondence between the $\delta^{18} \mathrm{O}$ level and the CI value; this would mean that a change in crystallinity would involve a change in the oxygen isotope ratio, thus pointing to substitution or degradation of phosphates (White et al. 1998). In this case, excluding the observed outlier, there is no relationship between CI values and oxygen isotope ratios (Pearson's; $y=1.88+0.05 x ; r^{2}=7.0 \% ; p>0.05$ ).

The ratio of apatite carbonates to phosphates $(\mathrm{C} / \mathrm{P})$ for samples from the three individuals ranges from $0.18-0.76$ (Fig. 6). For two samples, i.e., the femur of the individual from Grave $11(\mathrm{C} / \mathrm{P}=0.76)$ and the rib of the individual from Grave 12 
$(\mathrm{C} / \mathrm{P}=0.57), \mathrm{C} / \mathrm{P}$ exceeds 0.5 ; these values may indicate contamination by external carbonates.

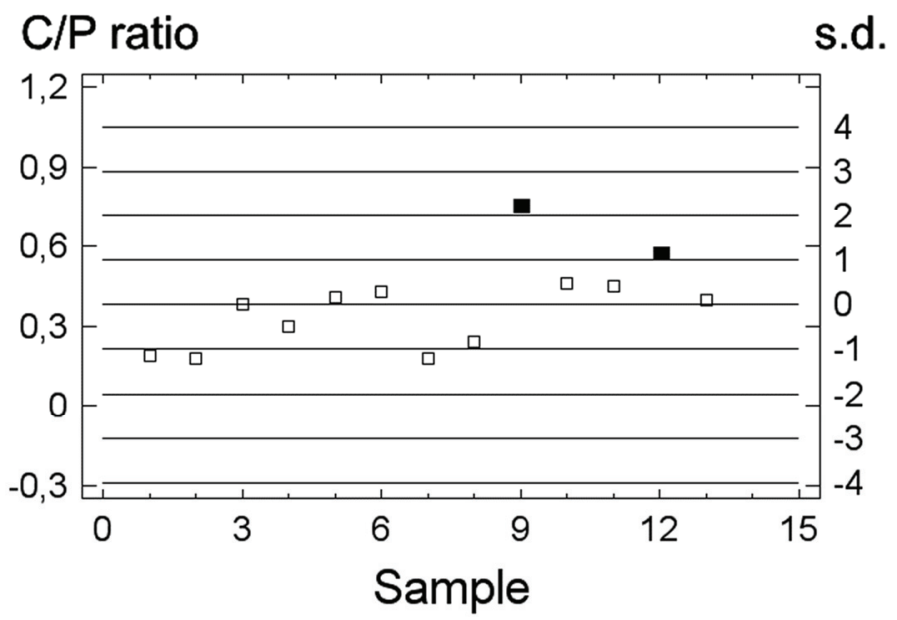

Fig. 6. Outlier plot with sigma limits for carbonate-phosphate ratio. Filled squared - signal of diagenetical alteration $(\mathrm{C} / \mathrm{P}>0.5)$.

An inverse relation between parameters C/P and CI (Pearson's; $y=1.66-0.44 x$; $r^{2}=36.7 \% ; p=0.053$ ) confirms the findings of others (Nielsen-Marsh, Hedges 2000). It is connected with the decreasing size of apatite crystals together with an increase in the number of carbonates from the soil incorporated into the crystalline lattice. The inverse relation is characteristic of taphonomically unchanged bones. The lack of correlation between $\mathrm{C} / \mathrm{P}$ and $\delta^{18} \mathrm{O}$ (Pearson's; $\mathrm{y}=0.59-0.01 \mathrm{x} ; \mathrm{r}^{2}=2.1 \% ; \mathrm{p}>0.05$ ), also observed, confirms that the carbonates did not significantly influence the oxygen isotope proportions in the skeletal material.

The intra-individual variability of $\delta^{18} \mathrm{O}$ values is presented below. Every $\delta^{18} \mathrm{O}$ value pertaining to an individual was plotted on the 'biological age' and 'bone turnover' scale. Figure 7 shows the variation in the $\delta^{18} \mathrm{O}$ values during the ontogenetic phases of the individual from Grave 10.

As mentioned above, every analytical method applied showed that osteological samples of the individual from Grave 10 were not diagenetically altered. The rapid decrease $(\sim 3 \%)$ in $\delta^{18} \mathrm{O}$ in dentine $\mathrm{M} 3$, vertebra and femur in comparison to dentin M2, enamel M2 and enamel M3 merits noting. This significant drop in the oxygen $\delta^{18} \mathrm{O}$ values may suggest a change in location (migration) of the analysed individual; this may have taken place about the age of 15 .

Figure 8 shows $\delta^{18} \mathrm{O}$ values for material from a one-year-old individual (Grave 11). As is generally known, breast-fed children display $2-4 \%$ greater $\delta^{18} \mathrm{O}$ values in their organisms when compared to adults from the same group. The introduction of weaning food into a child's diet causes the difference in tissue $\delta^{18} \mathrm{O}$ between children and adults to decrease gradually to levels characteristic of adult individuals (Wright, Schwarcz 1999). 


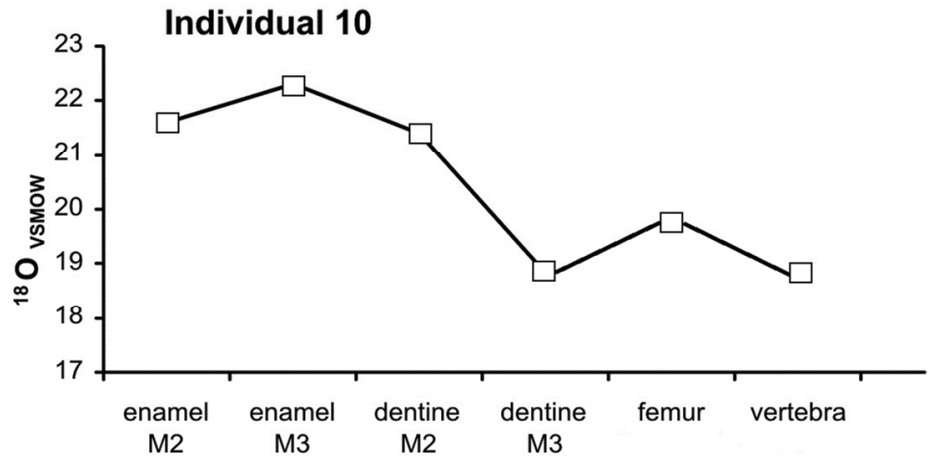

Fig. 7. Variation in $\delta^{18} \mathrm{O}$ values during the ontogenetic phases of the individual from grave no. 10.

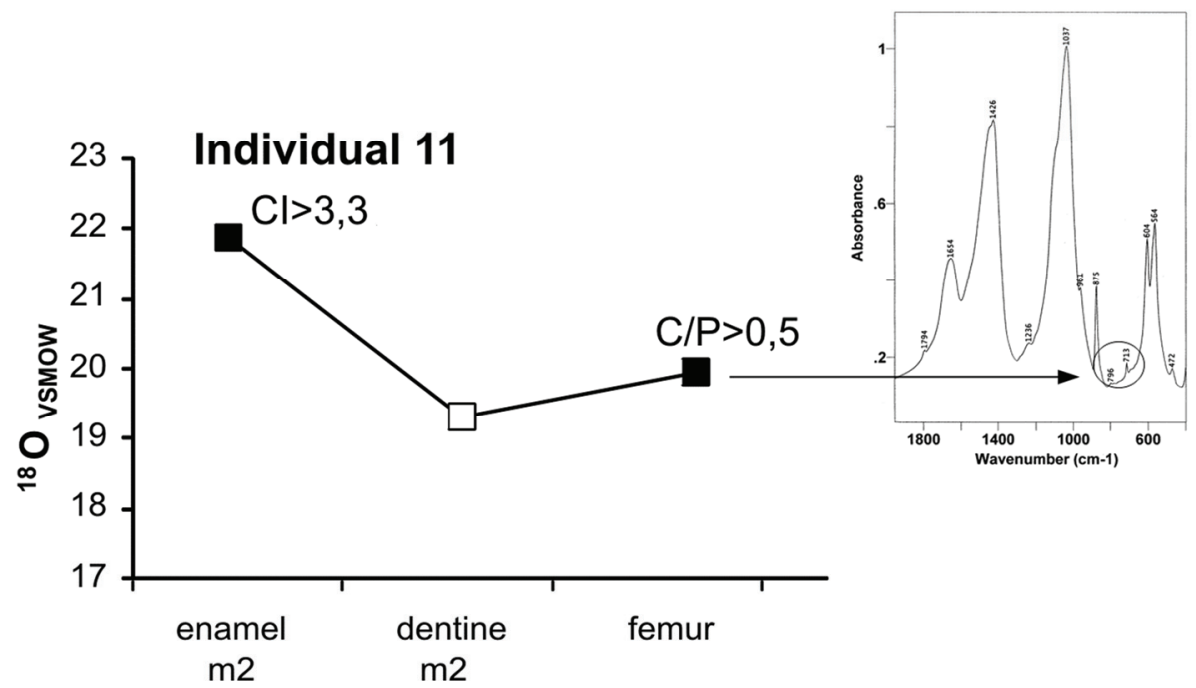

Fig. 8. Variation in $\delta^{18} \mathrm{O}$ during the ontogenetic phases of the individual from grave no. 11 with FTIR spectrum. Filled squared - quantitative and qualitative signals of diagenetic alteration (femur sample).

The ontogenetic variability in $\delta^{18} \mathrm{O}$ values for the one-year old individual (Grave 11) could suggest that weaning food was introduced when the infant was ca 4 months old ( $\sim 3 \%$ decrease of $\delta^{18} \mathrm{O}$ between enamel $\mathrm{m} 2$ and dentine $\mathrm{m} 2$ ). However, if the enamel $\mathrm{CI}$ is considered as too high although some authors give the limit as $\sim 3.5$ ), the bioarchaeological interpretation of a weaning effect is not possible. Moreover, potential signs of diagenetic alteration in the form of phosphate peaks were observed in the femur. In the analysed bone, the $\mathrm{C} / \mathrm{P}$ value was also exceeded. Conceivably, the exogenous addition of carbonate or silicate affected the analytical results though $\mathrm{Ca} / \mathrm{P}$ and $\mathrm{CI}$ values do not suggest diagenesis. 
In the light of the diagenetic changes observed in the enamel $(\mathrm{CI}>3.3)$ and femur (qualitative changes in phosphate peaks $\mathrm{C} / \mathrm{P}>0.5$ ), the attempt at reconstructing the weaning process should be approached more critically. Despite a clear drop in the $\delta^{18} \mathrm{O}$ value, the analysed individual must be excluded from any bioarchaeological interpretations.

Figure 9 shows the isotopic variability in different skeletal elements of a young individual from Grave 12. $\delta^{18} \mathrm{O}$ values for all samples of the young individual are similar, apart from the rib. Because values for $\mathrm{Ca} / \mathrm{P}$ and $\%$ collagen do not indicate any post mortem alteration, we can assume that this individual changed his environment for a short period of time; a distinct decrease of $\delta^{18} \mathrm{O}$ in the $\mathrm{m} 2$ dentine suggests so. This sample also has a much lower CI value than the others in the study, also consistent with contamination with some types of exogenous carbonates. But when the other diagenetic parameters of the rib are taken into account, i.e., the qualitative traits of the FTIR spectrum and excessively high C/P (0.58), modification probably caused by exogenous agents is suggested which necessitates exclusion of the sample necessary.

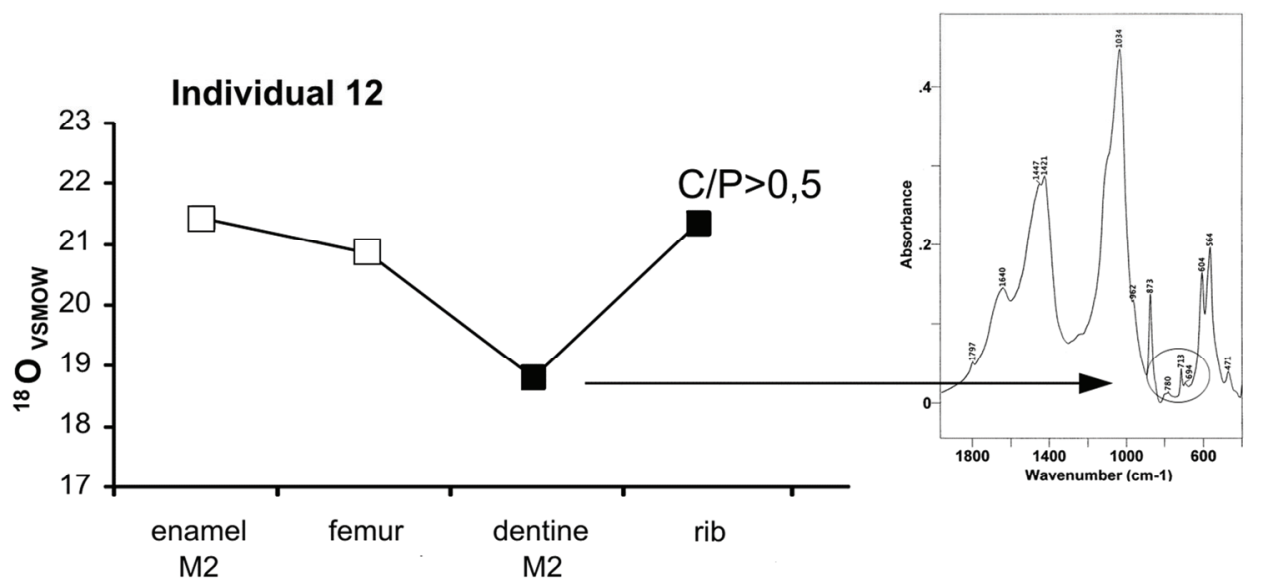

Fig. 9. Oxygen stable isotope variability in different elements of skeleton of youth individual from grave no. 12 on an FTIR. Filled squared - quantitative and qualitative signals of diagenetic alteration (dentine M2).

\section{Conclusion}

Multi-dimensional analyses has found, despite the lack of differences in soil acidity, that not all parts of a skeleton on a given site had been equally exposed to diagenetic post mortem changes. In addition, as far as the analysed skeletons are concerned, not all of their fragments had been altered to the same extent. In two cases, there is a peak in FTIR absorbance diagrams connected with silicates or exogenous carbonates in the vicinity of phosphate groups. What is more, increased $\mathrm{C} / \mathrm{P}$ values co-exist with qualitative changes in the spectra. The fact that the $\mathrm{CI}$ and $\mathrm{C} / \mathrm{P}$ values conform to the standard is very important. Oxygen from exogenous minerals may obviously distort the final results of the isotopic analyses. Thus, apart from quantitative calculation of $\mathrm{Ca} / \mathrm{P}, \mathrm{CI}, \mathrm{C} / \mathrm{P}$ and $\%$ collagen, 
qualitative analyses such as examination of the absorbance line and specification of the extent to which a sample is contaminated in the light of any additional, non-biogenic peaks.

It should be stressed that, for prehistoric material preserved in a similar macroscopic condition, variation in the ages of individuals at death and small differences in the deposition site may significantly influence taphonomic processes. As a result of these unpredictable factors, different degrees and intensities of diagenetic change characterise different parts of an individual skeleton.

In conclusion, we would like to emphasize that digenetic results observed in the osteological material provide geochemical information (relevant for geologists) and nonbiochemical information (relevant for anthropologists). This is the reason why for anthropological applications in elemental and isotope studies it is necessary to thoroughly analyse the material derived from site work (soil and bone samples) to assessing the organic and inorganic structure of bones and teeth.

\section{References}

Ambrose, S. H. (1993). Isotopic analysis of paleodiets: Methodological and interpretive consideration. In M. K. Sandford (Ed.), Investigations of Ancient Human Tissue: Chemical Analyses in Anthropology (pp. 50-130). Landorne PA: Gordon and Breach.

Ambrose, S. H. \& Norr, L. (1993). Experimental evidence for the relationship of the carbon isotope ratios of whole diet and dietary protein to those of bone collagen and carbonate. In J. B. Lambert \& G. Grupe (Eds.), Prehistoric Human Bone: Archaeology at the Molecular Level (pp. 1-37). Berlin: Springer-Verlag.

Ballasse, M. (2003). Potential biases in sampling design and interpretation of intra-tooth isotope analysis. International Journal of Osteoarchaeology 13(1-2), 3-10. DOI: 10.1002/oa.656.

Bell, L. S., Skinner, M. F., \& Jones, S. J. (1996). The speed of post mortem change to the human skeleton and its taphonomic significance. Forensic Science International 82(2), 129-140. DOI: 10.1016/0379-0738(96)019846.

Bocherens, H. (1997). Isotopic biogeochemistry as a marker of Neandertal diet. Anthropologischer Anzeiger 55(2), 101-120.

Brady, A. L., White, Ch. D., Longstaffe, F. J., \& Southam, G. (2008). Investigating intra-bone isotopic variations in biopatite using IR-laser ablation and micromilling: Implications for identifying diagenesis. Palaeogeography, Palaeoclimatology, Palaeoecology 266(3-4), 190-199. DOI:10.1016/j.palaeo.2008.03.031.

Buckberry, J. (2000). Missing, presumed buried? Bone diagenesis and the under-representation of Anglo-Saxon children. Assemblage 5, 1-14.

Child, A. M. (1995). Towards and understanding of the microbial decomposition of archaeological bone in the burial environment. Journal of Archaeological Science 22(2), 165-174. DOI:10.1006/jasc.1995.0018.

Collins, M. J., Nielsen-Marsh, C. M., Hiller, J., Smith, C. I., Roberts, J. P., Prigodich, R. V., Wess, T. J., Csapò, J., Millard, A. R., \& Turner-Walker, G. (2002). The survival of organic matter in bone: a review. Archaeometry 44(3), 383-394. DOI: 10.1111/1475-4754.t01-1-00071.

Dupras, T. L., \& Schwarcz, H. P. (2001). Strangers in a strange land: stable isotope evidence for human migration in the Dakhleh Oasis, Egypt. Journal of Archaeological Science 28(11), 1199-1208. DOI: 10.1006/jasc.2001.0640.

Evans, J. A., Chenery, C. A., \& Fitzpatrick, A., P. (2006). Bronze age childhood migration of individuals near Stonehenge, revealed by strontium and oxygen isotope tooth enamel analysis. Archaeometry 48(2), 309-321. DOI: $10.1111 / \mathrm{j} .1475-4754.2006 .00258 . x$.

Fabig, A., \& Herrmann, B. (2002) Trace elements in buried human bones: intra - population varability of $\mathrm{Sr} / \mathrm{Ca}$ and $\mathrm{Ba} / \mathrm{Ca}$ ratios - diet or diagenesis? Naturwissenschaften 89(3): 115-119. DOI: 10.1007/s00114-001-02947.

Goldstein, J. I., \& Yakowitz, H. (1975). Practical Scanning Electron Microscopy. New York: Plenum Press. 
Grupe, G., Dreses-Werringloer, U., \& Parsche, F. (1993). Initial stages of bone decomposition: Causes and consequences. In J. B. Lambert \& G. Grupe (Eds.), Prehistoric Human Bone: Archaeology at the Molecular Level (pp. 257-274). Berlin: Springer-Verlag.

Grupe, G., Piepenbrink, H., \& Schoeninger, M. J. (1989). Note on microbial influence on stable carbon and nitrogen isotopes in bone. Applied Geochemistry 4, 299.

Hedges, R. E. M. (2002). Bone diagenesis: an overview of processes. Archaeometry 44(3), 319-328. DOI: 10.1111/1475-4754.00064.

Jans, M. M. E., Nielsen-Marsh, C. M., Smith, C. I., Collins, M. J., \& Kars, H. (2004). Characterization of microbial attack on archaeological bone. Journal of Archaeological Science 31(1), 87-95. DOI: 10.1016/j.jas.2003.07.007.

Jarosz, P., Tunia, K., \& Włodarczak, P. (2009). Burial mound No. 2 in Malżyce, the district of Kazimierza Wielka / Grobowiec nr 2 w Malżycach, pow. Kazimierza Wielka. Sprawozdania Archeologiczne 61, 175-231.

Jørkov, M. L. S., Heinemeier, J., \& Lynnerup, N. (2007). Evaluating bone collagen extraction methods for stable isotope analysis in dietary studies. Journal of Archaeological Science 34(11), 1824-1829. DOI: 10.1016/j.jas.2006.12.020.

Kohn, M. J., Schoeninger, M. J., \& Barker, W. W. (1999). Altered states: Effects of diagenesis on fossil tooth chemistry. Geochimica et Cosmochimica Acta 63(18), 2737-2747. DOI: 10.1016/S0016-7037(99)00208-2.

Kondracki, J. (2000). Geografia regionalna Polski, Warszawa: PWN.

Krueger, H. W. (1991). Exchange of carbon with biological apatite. Journal of Archaeological Science 18(3), 355361. DOI: $10.1016 / 0305-4403(91) 90071-\mathrm{V}$.

LaPorte, D. F., Holmden C., Patterson W. P., Prokopiuk T., \& Eglington B. M. (2008) Oxygen isotope analysis of phosphate: improved precision using TC/EA CF-IRMS. Journal of Mass Spectrometry 44(6), 879-890. DOI: $10.1002 / \mathrm{jms} .1549$.

Lécuyer, C., Fourel, F., Martineau, F., Amiot, R., Bernard, A., Daux, V., Escarguel, G., \& Morrison, J. (2007). High-precision determination of ${ }^{18} \mathrm{O} /{ }^{16} \mathrm{O}$ ratios of silver phosphate by EA-pyrolysis-IRMS continuous flow technique. Journal of Mass Spectrometry 42(1), 36-41. DOI: 10.1002/jms.1130.

Lécuyer, C., Grandjean, P., \& Emig, C. (1996). Determination of oxygen isotope fractionation between water and phosphate from living lingulids: Potential application to palaeoenvironmental studies. Palaeogeography, Palaeoclimatology, Palaeoecology 126(1-2), 101-108. DOI: 10.1016/S0031-0182(96)00073-9.

Lee-Thorp, J. (2002). Two decades of progress towards understanding fossilization processes and isotopic signals in calcified tissue minerals. Archaeometry 44(3), 435-446. DOI: 10.1111/1475-4754.t01-1-00076.

Lee-Thorp, J., \& Sponheimer, M. (2006). Contributions of biogeochemistry to understanding Hominin dietary ecology. Yearbook of Physical Anthropology 131(43), 131-148. DOI: 10.1002/ajpa.20519.

Lee-Thorp, J.A., \& van der Merwe, N.J. (1991). Aspects of the chemistry of modern and fossil biological apatite. Journal of Archaeological Science 18(3), 343-354. DOI: 10.1016/0305-4403(91)90070-6.

Longinelli, A. (1984). Oxygen isotopes in mammal bone phosphate: a new tool for paleohydrological and paleoclimatological research. Geochimica et Cosmochimica Acta 48(2), 385-390. DOI: 10.1016/00167037(84)90259-X.

Luz, B., Kolodny, Y., \& Horowitz, M. (1984). Fractionation of oxygen isotopes between mammalian bonephosphate and environmental drinking water. Geochimica et Cosmochimica Acta 48(8), 1689-1693. DOI: 10.1016/0016-7037(84)90338-7.

Nielsen-Marsh, Ch. M., \& Hedges, R. E. M. (2000). Patterns of diagenesis in bone I: The effects of site environments. Journal of Archaeological Science 27(12), 1139-1150. DOI: 10.1006/jasc.1999.0537.

O'Neil, J. R., Roe, L. J., Reinhard, E., \& Blake, R. E. (1994). A rapid and precise method of oxygen isotope analysis of biogenic phosphate. Israel Journal of Earth Sciences 43, 203-212.

Pearsal, D. M. (2008). Paleoethnobotany. A Handbook of Procedures. Cornwall: MPG Books.

Reitsema, L. J, Crews D. E., \& Polcyn M. (2010). Preliminary evidence for medieval Polish diet from carbon and nitrogen stable isotopes. Journal of Archaeological Science 37(7), 1413-1423. DOI: 10.1016/j.jas.2010.01.001.

Schoeninger, M. J., \& Moore, K. (1992). Bone stable isotope studies in archaeology. Journal of World Prehistory 6(2), 247-295. DOI: 10.1007/BF00975551.

Sponheimer, M., \& Lee-Thorp, J. A. (2006). Enamel diagenesis at South African Australopith sites: Implications for paleoecological reconstruction with trace elements. Geochimica et Cosmochimica Acta 70(7), 1644-1654. DOI: 10.1016/j.gca.2005.12.022.

Stephan, E. (1997). Patterns of chemical change in fossil bones and various states of bone preservation associated with soil conditions. Anthropozoologica 25, 173-180. 
Szczepanek A. (2009). The anthropological analysis of skeletons from tomb no. 2 in Malżyce. Sprawozdania Archeologiczne 61, 233-242.

Thompson, T. J. U., Gauthier, M., \& Islam, M. (2009). The application of a new method of Fourier Transform Spectroscopy to the analysis of burned bone. Journal of Archaeological Science 36(3), 910-914. DOI: 10.1016/j.jas.2008.11.013.

Vennemann, T. W., Fricke, H. C., Blake, R. E., O’Neil, J. R., \& Colman, A. (2002). Oxygen isotope analysis of phosphates: A comparison of techniques for analysis of $\mathrm{Ag}_{3} \mathrm{PO}_{4}$. Chemical Geology 185(3-4), 321-336. DOI: 10.1016/S0009-2541(01)00413-2.

Weiner, S., \& Bar-Yosef, O. (1990). States of preservation of bones from prehistoric sites in the Near East: a survey. Journal of Archaeological Science 17(2), 187-196. DOI: 10.1016/0305-4403(90)90058-D.

White, T. D., \& Folkens, P. A. (2005). The human bone manual. Elsevier Accademic Press.

White, C., Longstaffe, F. J., \& Law, K. R. (2004). Exploring the effects of environment, physiology and diet on oxygen isotope ratios in ancient Nubian bones and teeth. Journal of Archaeological Science 31(2), 233-250. DOI: 10.1016/j.jas.2003.08.007.

White, C. D., Spence, M. W., Stuart-Williams, Q., \& Schwacz, H. P. (1998). Oxygen isotopes and the identification of geographical origins: the Valley of Oaxaca versus the Valley of Mexico. Journal of Archaeological Science 25(7), 643-655. DOI: 10.1006/jasc.1997.0259.

Włodarczak, P. (2006). Kultura ceramiki sznurowej na Wyżynie Małopolskiej. Kraków.

Wright, L. E., \& Schwarcz, H. P. (1996). Infrared and isotopic evidence for diagenesis of bone apatite at Dos Pilas, Guatemala: Paleodietary Implications. Journal of Archaeological Science 23(6), 933-944. DOI: 10.1006/jasc.1996.0087.

Wright, L. E., \& Schwarcz, H. P. (1999). Correspondence between stable carbon, oxygen and nitrogen isotopes in human tooth enamel and dentine: infants diets at Kaminaljuyú. Journal of Archaeological Science 26(9), 1159-1170. DOI: 10.1006/jasc.1998.0351.

Yoshino, M., Kimijima, T., Miyasaka, S., Sato, H., \& Seta, S. (1991). Microscopical study on time science death in skeletal remains. Forensic Science International 49(2), 143-158. DOI: 10.1016/0379-0738(91)90074-S

Zazzo, A., Lécuyer, Ch., \& Mariotti, A. (2004). Experimentally controlled carbon and oxygen isotope exchange between bioapatites and water under inorganic and microbially mediated conditions. Geochimica et Cosmochimica Acta 68(1), 1-12. DOI: 10.1016/S0016-7037(03)00278-3. 